\title{
Joged Mataram: The Concept of Dance Applied in the Present Community Life
}

\author{
Yuli Sectio Rini ${ }^{1}$ \\ ${ }^{1}$ Yogyakarta State University, Yogyakarta, Indonesia \\ *Corresponding author. Email: twidyarizkyananda@gmail.com
}

\begin{abstract}
The concept of Joged Mataram is an understanding that must be mastered by dancers who are learning Javanese dance. The mastery of Joged Mataram is significant for people who are learning dance to understand that learning dance beside the physical skills, it must also understand the concepts of dance. Therefore, an understanding of Joged Mataram is essential to discover its urgency and relevance in dance life as well as in everyday life. Joged Mataram is a Javanese dance concept that can be applied in everyday life especially in this life when people have been influenced by various things. Joged Mataram consists of four elements which are Sawiji, Greget, Sengguh, and Ora Mingkuh. Each of which has an understanding and can be implemented in social life. Sawiji is total concentration. A dancer must be able to focus on the performed role. Because of the full concentration, the atmosphere or events around him will not be able to bother the concentration. Greget is the spirit or dynamics in the soul of a dancer. The burning spirit of dancers must be controlled and directed to the appropriate way of dance. The emotion of the dancer must be directed so that they can dance with a subtle feeling. Greget which is an inner dynamic is also a dancer's talent, so it cannot be trained to other dancers. Sengguh is self-confidence in dancers which does not lead to pride. Believing in himself is very important for dancers, because dancers must be sure that they dance appropriately and correctly both according to his movements and the standards. Sengguh is the attitude of a dancer who must be blended into the dance moves. He or she moves to convey a mission to the audience. The last one is Ora Mingkuh, which is keeping things that are the responsibility. Courage, strength, and loyalty are three things in dealing with situations. The four things in Joged Mataram are local wisdom that is the concept of philosophy in dancing. The concept can be applied to society in everyday life. Especially now that people face various things in their lives such as globalization, things that happen in society, negative influences, and so on. Society is now in the era of industrial development. Hence, it will affect both individuals and the wider community. If the community or individuals can apply the concept in Joged Mataram, the person or community will be able to encounter the development of the era in the industrial era now and later.
\end{abstract}

Keywords: Joged Mataram, concepts, communities, period development.

\section{INTRODUCTION}

The dancer must master Joged Mataram, because besides dancers mastering dance moves, dancers must also understand the concepts in dance. Therefore, understanding about Joged Mataram is important for the dancers to find their urgency and relevance. Sri Sultan Hamengku Buwana I (1755-1792) stated that in addition to movement, classical dance in the Yogyakarta style also demanded that the feeling was also adjusted to the philosophy of life in shaping character. Yogyakarta style dance with concept Joged Mataram serves as a means of forming characters. It can be explained as follows, dance is part of education in the palace, both Yogyakarta Palace and Surakarta Palace. Dance is also a must subject for $a b d i$ dalem (servant) of the palace and the royal family, because dance is related to culture. So the palace has educated abdi dalem in order to be cultured and have character. Dance also teaches that one must be full of personality as it is also called that the art of dance has the personality of the archipelago, which contains beauty and grandeur.

There are four characters contained in the concept of Javanese dance in Yogyakarta namely Joged Mataram. This concept can also be called a philosophy, i.e. Sawiji, Greget, Sengguh, and Ora Mingkuh. The details are as follows. Sawiji is total concentration. Because of his totality, the events around him did not shake his concentration. Greget that is the spirit of the dancer's soul. The burning spirit of dancers must be controlled and channeled in the right direction. Greged is an inner dynamic which leads to dancer's character. Next, Sengguh 
is confidence in dancers. Confidence is very important for dancers, because dancers must be sure that they dance properly and correctly according to pathokan(laws and rules in dance movements). Sengguh is the attitude of a dancer who blends in with his dance moves. They move to convey a mission to the audience. The last one is Ora Mingkuh that is, doing things that are their responsibility. Courage, strength, and loyalty are three things in dealing with situations.

The four inner elements of Joged Mataram are local wisdom from the concept of philosophy in dancing. If you pay attention to the contents of Joged Mataram, then the concept can be applied to society in everyday life. Today is the era of industrial development. If people have a life attitude as in Joged Mataram, then when face all problems or events in life, the person can deal with them wisely. People in their lives often face various things in their lives such as globalization, negative and positive influences, and so on. Thus if a society consisting of a collection of individuals and vice versa individuals are members of the community, it will create a society that has personality and character.

We all know that art - including dance - has an important role in education. It also definitely included in character education. On the other hand, the Law of the Republic of Indonesia No. 20 of 2003 concerning the National Education System requires that arts and cultural education to be included. Art education is given to students not to become artists, but to instill a sense of sensitivity to aesthetic, ethical, logical, and considerate values. In addition, art education also helps to develop psychological aspects and foster a sense of pride in one's own nation, as well as preserving cultural arts. If art education is carried out appropriately, in addition to making students intelligent and creative, they also have a feeling of being refined, cultured, and respectful of others. Students are also individuals and part of the community. This will make daily life in the midst of society more organized and characterized. Participants are also able to develop thinking and human life as members of the community.

Indonesia is currently being hit by various social and political problems. As a developing country, Indonesia faces various problems. The community is being hit by various crises. This is due to various factors. Many problems that arise in society. As revealed by Sumaryono [3] that people are experiencing points of change and shifts in various aspects of life. Sumaryono revealed that there are 3 things that affect the community, namely (1) the social, political, and cultural development of Indonesian society in general; (2) the spirit of nationalism to the formation of national culture; and (3) the flow of industrialization, the development of communication technology, and the era of globalization that marks the world as it is today.

On the other hand, the present generation has placed art as a secular spectacle, only giving pleasure, but the meanings in it are not understood. Some of the present generation no longer consider traditional learning as wisdom. The current generation considers it obsolete. Many events are ironic and far from moral behavior. This indicates that the community has been contaminated by negative things. For example brawls, students threatening their teachers, fathers raping children, chaotic traffic that is drivers who do not obey traffic rules, selfish drivers who do not think about the interests of others, corruption, and others. These problems will more or less affect people's lives. The development of society also affects both individuals and the wider community. If an individual or community can apply the concept Joged Mataram in itself, the concept which full of teachings about morals, ethics, and character, then the community will also be able to face the development of the times in the current industrial era and in the future era.

\section{RESEARCH METHOD}

There is a kind of humanities education in society. This humanities education teaches about human values that are part of the cultural system. Humanities education is determined by the knowledge system that is owned by the community. Kuntowijoyo found 3 humanities education in traditional Javanese society namely palace, boarding school, and college. Of these three things, then Joged Mataram what is mentioned in this paper is education in the palace. Education in this palace can be applied in the community. According to Gurvitch in Kuntowijoyo [1], royal society, feudalistic, placed the first philosophical and theological knowledge system. So it can be said that the order of priorities has a direct bearing on social position. The people who live in the palace represent a feudal society or a palace that has a great opportunity and philosophically explain the basics of community existence [4]. Life in the palace is full of philosophical things. But inside the palace there are creative works such as representative art. In addition, the palace also flows values and symbols. Means that in the palace there is an art education for its people. It also includes education about Joged Mataram.

Educational content in the palace varies, according to interests. Kawruh in the palace in general are ethical, in various fields [4]. In the palace it is also said that there are 26 lessons ranging from ethics, social, language, religion, philosophy, and among them are art. Thus it can be said that humanities education was also given in the palace. Caturwati explained that art is the totality of life, art contributes a lot to society and shapes characters, attitudes, behavior, and language [3]. It was also explained that art education in the past was delivered naturally, starting in the family, community groups, and school environment. Humanities education has essential and unique functions, thus arts education cannot be replaced with others. Philosophically, art has a unique role, in education that is in accordance with the changes and dynamics of society [3] So it can be said that art education is a human need or human needs as expressed by the people "need for selfactualization, needs for meaning, social needs, aestehic needs, and survival needs. Pratt's statement shows that aesthetic needs seen as an essential part. Because semi 
dance is one branch of art, it can be concluded that dance education is also an art education.

Then it can be explained also that dance education in Indonesia, especially in the palace environment is a classical style of dance education, which tends to have grips and values that must be obeyed. Thus dance lessons and education can be a medium for contextual life-planting values so that it greatly helps the process of character building.

\section{RESULTS AND DISCUSSION}

Joged Mataram as an education about the taste for dancers who originally existed in the palace. Then later studied in the middle of the wider community. See the contents, then the concept Joged Mataram this can be applied in everyday life in the community. We see the contents contained in philosophy of Joged Mataram can be practiced by the community. Therefore, philosophy Joged Mataram it should also be socialized to the wider community. The following is the philosophy contained in Joged Mataram that is Sawiji, Greget, Sengguh, and Ora Mingkuh.

Sawiji is total concentration but does not cause mental tension. A dancer must be in a situation where all of his attention is focused on the role he is carrying (total concentration), someone does not forget themselves (trance). Someone according to their duties and work must concentrate in the field that they do. Any event in the vicinity will not affect it. This will be very useful in everyday life. Someone will does the job or task in his life well if someone is doing it with full of concentration. His role in life will be carried out with full concentration. Become one with work. As a student, when studying, as a lecturer when teaching, as an employee when doing work, as a pilot when controlling a plane, and so on. All done with full concentration.

Greged is dynamics or passion (inner dyamic). Innate from within one's soul. Greged is the spirit that comes from the dancer herself, and does not have to be done with a selfcontrol. Existing emotions must also be restrained and controlled so as not to lead into a rough form. One must have the spirit in accordance with the duties and work. Someone working or doing anything must be with enthusiasm in his soul.

Sengguh is the next element, self confidence which does not lead to pride (without being arrogant). Believing in yourself is very important in a dancer. In this case the dancer as a member of the community must also be confident so that it can be said that the community must also be confident. Thus, a person both as an individual and as a society must have confidence.

Ora Migkuh is the last element in science of Joged Mataram. Ora Mingkuh means abstinence (no-retreat). In addition, it is also full and responsible. This signifies determination, loyalty, and courage in any situation. Not afraid to face difficulties. Face all problems with courage and firmness.

Philosophy Joged Mataram if it is applied in the art of dance will provide a physical and mental balance. So if it is applied to the people outside the palace, it will also bring physical and spiritual balance. Dancing is physical education and beauty or aesthetic education. It was even explained that dancing was an effort to build a sense of love for culture. In addition to the community as well as a weapon to instill characteristics traits. Joged Mataram as character education in this dance can be used as a medium to refine character. Philosophy of Joged Mataram as a concept of life guidelines. Sawiji interpreted as a hard effort in realizing ideals based on concentration on the main goal. Greged is an embodiment of directed spirit through reasonable channels. Sengguh is confidence in one's abilities. Then finally Ora Mingkuh is a fighting spirit without giving up on existing obstacles. Philosophy Joged Mataram this is very suitable to be understood in life of the community. Even in the past people had assumed that if they did not understand Joged Mataram, someone will be considered uneducated.

Joged Mataram can also be interpreted broadly. How to deal with fellow human beings socially (horizontally) and vertically with their creators must be good. Joged Mataram also instills gratitude in someone. This is the most important thing in life. Principle in Joged Mataram also instill the element of decency that is when people dance should not violate immorality. In addition, a person must be disciplined and stand firm. The concept can be applied in everyday life. Especially in this life when globalization spread.

\section{CONCLUSION}

The conclusion is that Joged Mataram is a normative concept for dancers. Of contents Joged Mataram then it can be said that the normative aesthetic concept Joged Mataram not only applied to dancers. But the concept Joged Mataram can also be applied to the wider community today. This concept can be applied in the community.

\section{REFERENCES}

[1] Gurvitch, George. The Social Framework of Knowledge. New York: Harper \& Row, Publisher. 1971.

[2] Caturwati, Endang. "Tari Pendidikan Karakter Bangsa Pendidian Seni dan Pembentukan Karakter [Dance Education, Character Education Arts Education and Character Building]." Dalam Dialektika, Seni Dalam Budaya Masyarakat [In Dialectics, Arts in Community's Culture]. Yogyakata: Badan Penerbit ISI Yogyakarta. 2013.

[3] Sumaryono. Dialektika Seni dalam Budaya Masyarakat [Dialectic Art in Community's Culture]. Yogyakarta: Balai Penerbit ISI Yogyakarta. 2013. 
[4] Kuntowijoyo. Budaya dan Masyarakat [Culture and Society]. Edisi Paripurna. Yogyakarta: Tiara Wacana. 2006

[5] Kuswarsantya, dkk. Edit. Greged Joged Jogja.Nili, Seni, dan Pendidikan [Greged Joged Jogja.Nili,Arts, and Education]. Cetakan Pertama. Yogyakarta: Bale Seni Condroradono ISI Yogyakarta, Universitas Negeri Yogyakarta, SMKI Yogyakarta. 2012.

[6] Wibowo, Fred. Tari Klasik Gaya Yogyakarta [Yogyakarta's style of Classical Dance]. Jogjakarta:

Yayasan Bentang Budaya. 2002 